Ankara Üniversitesi Ĕ̆itim Bilimleri Fakültesi Dergisi, yıl: 2004, cilt: 37, sayı: 1 ss 55-77

\title{
Etkileşimsel Model’e Uygun Okuma Öğretiminin Türkçe Bilgilendirici Metinleri Anlama Düzeyine Etkisi*
}

\begin{abstract}
Tülay Sarar KUZU**
ÖZ: $\mathrm{Bu}$ çalışmada, metindilbilim tabanlı bilişsel bir okuma modeli olan Etkileşimsel Model'in temel alındığı bir okuma öğretiminin, öğrencilerin Türkçe bilgilendirici metinleri anlama düzeylerine etkisi araştırılmıştır. Bu çalışma deneysel bir çalışma olarak planlanmıştır ve deneysel model olarak "Kontrol Gruplu Ön ve Son Test Modeli" kullanılmıştır. Bu araştırma üniversite birinci sınıf öğrencileri üzerinde gerçekleştirilmiştir. Veriler, araştırmacı tarafından geliştirilen ve okuma becerisinin kavrama ve uygulama düzeyini ölçen, kısa yanıtlı 20 sorudan oluşan "Okuduğunu Anlama Becerisi Ölçme Aracı" ile elde edilmiştir. Elde edilen veriler bilgisayar ortamına aktarılmış; yapılan istatistiksel analizler sonucunda deney grubu lehine anlamlı fark bulunmuş ve çalışmanın denenceleri doğrulanmıştır. Etkileşimsel Model'in öğrencilere okuduğunu anlama becerisinin "kavrama" ve "uygulama" düzeyindeki davranışları kazandırmada ve ayrıca okuduğunu anlama becerisini bütünleyen davranışları kazandırmada (toplam erişide) geleneksel yönteme göre daha etkili olduğu saptanmıştır.
\end{abstract}

Anahtar Sözcükler: Okuma stratejileri, Etkileşimsel Model, bilgilendirici metin

\section{The effect of teaching reading strategies based on interactive model on Turkish informative text}

\begin{abstract}
In this study, Interactive Model which is a textlinguistic based cognitive reading model has been used to investigate the effect of this model on the students' comprehension and application level of informative texts in Turkish. This study has been planned as an empirical study, and as an ampirical model the "Pre and Post Test with Control Group" has been used. This research has been conducted with the freshman students at Başkent University, for 10 weeks. The data which is necessary to test the hypothesis of the study, have been obtained by "The Reading Comprehension Skill Scale" with 20 short answers developed by the researcher. The data has been processed in the computer and as a result of the statistical analyses a wide range of difference has been found in favour of the sample group. Thus the hypotheses of the study have been approved. It has been discovered that the Interactive Model has a greater effect on the improvement of comprehension skills in the understanding and application levels and on the improvement of other skills that support comprehension than the traditional model.
\end{abstract}

Key Words: Reading strategies, Interactive Model, informative text

\section{GİRIş̧}

\footnotetext{
* "Etkileşimsel Model'e Uygun Okuma Öğretiminin Türkçe Bilgilendirici Metinleri Anlama Düzeyine Etkisi" konulu doktora tezinin özetidir.

** Dr., Başkent Üniversitesi Dil Araştırma ve Uygulama Merkezi Öğretim Görevlisi
} 
Bu bölümde araştırmanın yapılma gerekçesini oluşturan problem, problem tümcesi ve alt problemler ile çalışmanın amacı ve önemine yer verilmiştir. Ayrıca, araştırmanın temel sayıltıları açıklanmış, araştırmayla ilgili bazı terimlerin tanımları yapılmış ve araştırmanın sinırlılıkları belirtilmiştir.

Dilbilim ilke ve bulgularının değerlendirilerek anadili ve yabancı dil alanlarında uygulamaya yönelik olarak ele alınması; yani kuramsal bilginin uygulama düzleminde karşılığını bulmak ve onları uygulamada sınamak, uygulamalı dilbilimin temelini oluşturmuştur. Bir bilginin kullanılabilir olması, dilbilimsel değeri ve geçerliliğinin ölçütü olarak görülmektedir. Bu durum kuramsal bilginin eğitim ortamına taşınması gereğini gündeme getirmektedir. Ayrıca,

"Anadili dersinin çok yönlü ve girişik nitelikli oluşu, bilgiden çok beceri ve alışkanlık geliştirmeyi amaçlaması; Türkçe öğretiminde öğrencilere istenilen öğrenme yaşantılarının kazandırılabileceği etkili eğitim durumları'nın seçilip düzenlenmesi işini daha da önemli kılmaktadır. Türkçe derslerinde, öğretim programlarında amaçlanan davranışların her bir öğrenciye kazandırılması, uygulanagelen geleneksel öğretim yöntemlerinde yenilikler ve değişiklikler yapmayı ya da yeni öğretme-öğrenme modellerini kullanmayı gerektirmektedir" (Sever, 2000:273).

Dilbilimcilerin son yıllarda üzerinde önemle durdukları söylem çalışmaları, iletişimi temel aldığı için, öğrenci odaklı bir Türkçe öğretimine ve dil yaratıcılığına olanak sağlamaktadır. Bunun yanısıra, dört dilsel becerinin bir arada kazandırılmasına olanak sağlamakla da tümleşik öğretime katkıda bulunmaktadır. Dil kullanımında bağlamı, yapı-işlev bağıntısını, dilin işlevsel kullanımını konu alan bu yaklaşımın Türkçe öğretimine yansıtılması, anadili öğretiminin bilimsel olarak temellendirilmesinin bir gereğidir. Çalışmamızın bir çıkış noktasını bu gereklilik oluşturmuştur.

Sözlü ve Yazılı Anlatım dersleri kapsamında yapılan metin inceleme çalışmaları sırasında, öğrencilerin okuma sürecinde metnin içeriğini tam anlamıyla kavrayamadıkları, metindeki dilsel, dilbilgisel düzenlenişi, arkaplan bilgileriyle yeterince etkileşime sokan etkin bir okuma gerçekleştiremedikleri gözlenmektedir.

$\mathrm{Bu}$ çalışmada, okurun anlamlandırma sırasında metin yüzeyindeki dilsel, dilbilgisel düzenlemeyi işlemleyerek dünya bilgileriyle (yaşam deneyimi, artalan bilgisi, zihinsel şemalar) etkileşime soktuğunu kabul eden Etkileşimsel Model'e uygun bir okuma öğretiminin, üniversite öğrencilerinin kavrama ve uygulama düzeyindeki becerilerine katkısı araştııılmış ve Türkçe öğretimine katkıda bulunabilmesi umuduyla, elde edilen veriler ışı̆̆ında önerilerde bulunulmaya çalışılmıştır. 


\section{1. Problem}

Anadili öğretiminin bütün aşamaları için saptanan amaçlar, genel olarak bakıldığında, bireylere anlama ve anlatma ile ilgili dilsel beceri ve alışkanlıkların kazandırılmasına yöneliktir. Bu becerilerin kazandırılması ise; dinleme, konuşma, okuma ve yazma gibi tümleşik dört ana etkinliğe dayanır. Dil becerileri, bu dört etkinlik alanının birbirini bütünleyen ilişkileri içinde edinilir. Becerilerin tümünün bir denge içinde geliştirilmesi, bireyin anadilindeki yeterliliğini belirleyen en temel ölçüttür (Sever, 2000).

Günümüzde, iş ve okul yaşantısının birçok kademesinde anadili kullanımının görünümleri, anadili öğretiminin bu iki boyutunda da önemli sorunlar olduğunu ortaya koymaktadır. Ancak ilk ve orta öğretimde uygulanacak, dilbilimsel bulguları temel alan ciddi ve özenli bir anadili öğretimi sayesinde, öğretimin üst basamağında yer alan üniversitelerde, temel düzeydeki bilgileri içeren anadili öğretimi gereksiz kılınabilecek; ya da öğrencilerin beğenisini ve yaratıcılığını geliştirmeye dönük daha üst düzeyde düzenlemeler içeren bir ders durumuna gelebilecektir.

Birçok gelişmiş ülkede olduğu gibi, ortaöğretimden geçmiş her gencin anadiline egemen olması ve ileri derecede bir iletişim yeteneği kazanabilmesi; doğru programların oluşturulması, nitelikli öğretici kadrosu, uygun araç, gereç ve fiziki ortamın sağlanması ve kendi türünü gerçekleştirmiş doğru metinler aracılığıyla okuma alışkanlık ve becerisinin kazandırılması ile mümkün olabilecektir.

Anadili öğretimindeki temel amaçlardan biri, bireyin iletişim yetisini en üst noktada işlemlemekken, bir diğeri problem oluşturabilecek ve aynı zamanda çözebilecek bir bilişsel yap1 oluşturmaktır. Anadili öğretiminin, salt bilgi aktarımı yerine, düşünme yeteneğini geliştirici bir yöntemle yapılması gerekir. Anadili öğretimiyle sağlanabilecek düşünsel gelişim çizgisi şöyledir:

1. Açık ve mantıklı düşünme yeteneği

2. Çözümleme yeteneği

3. Sentez yeteneği

4. Usa vurma, muhakeme yeteneği

5. Eleştirme yeteneği

6. İmgeleme

7. Belleği güçlendirme, ezber yeteneği

8. Sezgisel düşünme gelişimi

a) Algilama

Bu düşünsel gelişim de dört temel eylem çerçevesinde tanımlanmaktadır:

b) Uslamlama

c) Yorumlama

d) Yargilama 
Dil didaktiği, bu dört eylemin dil öğretimi ortamlarındaki izlenceler ve etkinliklerle nasıl etkinleştirileceği konusuna eğilir (Aydın 2001; Keçik ve Uzun 2002).

Anadili öğretimi dilin yapısından tamamen kopuk olmadığ gibi, tek başına dilbilgisi öğretimi demek de değildir. Anadilini öğretmek, dilin yapısının kullanımdaki görünümlerinin farkına varılmasını sağlamak demektir. Çünkü yapı kullanım ile şekillenmektedir.

Dili iletişim dizgesi olarak görmek ve kullanım boyutuna geçmek söz konusu olduğunda, metin dilsel birim olarak karşımıza çıkmaktadır. Dilbilgisi kuralları çok iyi bilindiğinde bile duruma uygun sözce üretilememesi ve ardışık bir çok tümceye karşılık bir tek sözcenin büyük bir edim gücü taşıması, dilbilimcileri dilbilgisinin, tümcenin ve dilin ötesine geçmeye zorlamıştır. Söylem çalışmaları, iletişim olgusunu anlamak için dilden yola çıkarak dilin ötesine geçmeyi amaçlayan çalışmalardır (Kocaman, 1998: 102). $\mathrm{Bu}$ çalışmalar Brown ve Yule (1983)'da "kullanımdaki dilin incelenmesi" olarak tanımlanmaktadır.

Öğrenciler özellikle, üst dil kullanılan bilimsel metinlerle, örtük anlatımın yeğlendiği yazınsal metinlere, anlayamayacakları ön yargısıyla yaklaşmaktadırlar. Kendi eksikleri olarak gördükleri bu durumla yüzleşmemek için ve aynı zamanda etkin bir edim olan -bu yüzden de görsel öğrenmeye göre sıkıcı ve yorucu olduğunu düşündükleriokumanın sağlayacağı düşünsel ve duyuşsal zenginliğin ayırdına varamadıkları için, bu tür metinlere uzak durmaktadırlar. Metni kavramaya yönelik yönlendirme çalışmaları ve buna eklenen eğitimbilimsel güdüleme yöntemleri sonucu, kavrama ve yorumlama güçlerinin ayırdına vardıklarında, öğrencilerin metne, dolayısıyla da okumaya karşı ilgilerinin artacağı düşünülmektedir.

Öğretme-öğrenme sürecinde okumanın büyük bir yere sahip olması, bu süreçte gerçekleşen öğrenmelerin, öğrencilerin okuduklarını anlama güçlerine bağlılığını artırmaktadır. Özellikle, ders kitapları dışındaki öğretim gereçlerinin az kullanıldığı eğitim ortamlarında, okuduğunu anlama, başlıca öğrenme yolu durumuna gelebilmektedir. Bu durumda, okuduğunu anlama gücü yüksek olan öğrencinin öğrenmesi kolaylaşmakta, düşük olanın ise zorlaşmaktadır (Özçelik, 1987:101).

Öğretimin ilk yıllarından başlayarak öğrencilerin okuduğunu anlama, giderek de üst düzey bilişsel işlemler olarak yorumlama ve değerlendirme güçlerinin geliştirilmesinin, eğitim ve öğretimin - amaç ve hedefleri doğrultusunda - etkinliğini ve verimini artıracağı düşünülmektedir.

$\mathrm{Bu}$ deneysel çalışmada etkinliği sınanan Etkileşimsel Model, okuma sırasında bilişsel ve zihinsel süreçlerin anlamı yorumlamadaki işlevini etkin kılacak bir okuma modelidir. Rumelhart tarafından 1977'de oluşturulmuş, 1984'te, etkili okuma becerisini kazanmış yetişkin bireylerle yapılan laboratuvar çalışmaları sonucunda geliştirilmiştir. 
Kuramsal olarak, farklı bilgi kaynakları arasında etkileşim olduğunu; beynin anlamlandırma sürecinde sözcük, tümce, metin içi bağlam, metin dışı bağlam arasında sürekli bir etkileşimsel ilişki kurduğunu savunur. Rumelhart'ın modeli; beynin anlamsal, yapısal, bağlamsal, bu çok yönlü ve bilgi kaynaklarından kendisine eşzamanlı ulaşan bilgileri işlemleme özelliğini öne çıkardığı için önemlidir.

Arkaplan bilgileri; dünya bilgisi, yaşam deneyimleri ve özel bir alana ait bilgileri içeren artalan bilgisi gibi, okurun kendisine ait, önceden edinilmiş bilgilerdir ve şema olarak adlandırılırlar. Şema kuramı da, arkaplan bilgilerinin okuma anlamadaki rolünü ele alan kuramdır. Bu kuramın temel dayanağı, yazılı ya da sözlü olsun, bir metnin okurun bilgileri olmadan tek başına anlam taşımayacağıdır. Bu kurama göre, aslında metin yalnızca okurun önceden edinilmiş bilgilerini harekete geçirmesi ve bu yolla anlamı kurması için yönlendirme sağlar. Eğer okur okuduklarını dünya bilgisi ile ilişkilendirebilirse, yani şema dediğimiz bu bilgi haritalarını etkin kullanabilirse etkili okuma-anlama becerisine ulaşabilir. Etkileşimsel Model'e işlerlik kazandıracak okuma stratejileri öğretimi de öğrencilerin okuma konusundaki özerkliklerini; yani kendi okumalarını yönlendirmelerini sağlamayı amaçlamaktadır.

Anadolu Üniversitesi tarafından gerçekleştirilen, metnin derin yapısındaki anlama ulaşmada en fazla kullanılan strateji olarak soru sorma'yı konu alan proje çalışması sonuçları bize okuma çalışmalarında; metin tabanlı, iç doğrultulu, tüme varımlı bir yaklaşımın benimsendiğini; metnin işlemlenmesi sırasında dünya bilgilerinin yeterince devreye sokulmadığını göstermektedir (Emeksiz, 1999).

Yine Bilkent Üniversitesinde, yabancı dil öğretiminde, üniversite birinci sınıf öğrencileri üzerinde yapılan bir tez araştırmasının sonuçları (Çelik, 1998) yorum gücünü kullanarak anlamlandırmaya giden etkin okurların içerik tabanlı stratejileri metin tabanlı olanlardan daha çok kullandıklarını, yani daha çok dış doğrultulu (dıştan içe) bir yaklaşım içinde olduklarını ortaya koymuştur. Bu durum, okurların okuma-anlama sürecinde dünya bilgilerini kullanarak sorular ürettiklerini, tahminlerde bulunduklarını ve bu tahminlerini sınadıklarını göstermektedir.

Öğretim sistemimizde var olan okuma eğilimleri izlendiğinde, öğrencilerin iç doğrultulu, metin merkezli bir yaklaşım izledikleri ve metinle edilgen bir etkileşim içinde oldukları gözlenmektedir. Oysa anlamlandırma sürecinde beyin, metin içi bağlam (sözcük, tümce ve onların bağlam içinde kazandıkları anlam) ile metin dışı bağlam (dünya bilgisi ve zihinsel şemalar) arasında sürekli ilişki kurmaktadır. Bütün bu farklı bilgi kaynakları birbirini etkilemekte, birbirleriyle etkileşimsel bir ilişki içinde bulunmaktadır. Etkileşimsel Model (Interactive Model), zihnin bu işlemleme özelliğini ön plana çıkararak anlamlandırmayı kolaylaştıran bir modeldir (Rumelhart, 1980). Bu bilgiden hareketle, bu çalışmada, Etkileşimsel Model'e uygun okuma öğretimi ele alınmıştır. Metindilbilimsel çerçevede ele alınacak olan Etkileşimsel Model'e uygun metin okuma çalışmaları, uygun okuma-anlama stratejileri ile desteklenmiştir. 


\section{Problem Tümcesi}

Okuma öğretiminde, Etkileşimsel Model'e uygun çağdaş okuma teknik ve yöntemleri (reading strategies) nin öğretildiği grubun öğrenmede ulaştıği erişi düzeyi ile bu teknik ve yöntemlerin uygulanmadığı, geleneksel yöntemle ögretim yapılan grubun öğrenmede ulaştı̆̆ 1 erişi düzeyi arasında anlamlı bir fark var mıdır?

\subsection{Amaç}

$\mathrm{Bu}$ çalışma, eğitbilimsel ve dilbilimsel veriler 1şı̆̆ında gerçekleştirilen Etkileşimsel Model'e uygun okuma öğretiminin, öğrencilerin bilgilendirici metinleri okuma, anlama, yorumlama sürecine katkıda bulunup bulunmadığını saptamayı amaçlamaktadır.

\section{3. Önem}

Oğuzkan (1991:78), okumanın önemini şöyle vurgular:

"Okuma bireyin duygu ve davranışlarına zenginlik ve renk katar, insanlara ve doğaya yansız ve hoşgörü ile bakmayı öğretir, /.../ kişinin dünya görüşü genişler, bilgisi artar, beğeni düzeyi yükselir. Kişiyi düşünme ve yaratma özgürlüğüne kavuşturur. Okuma, uygarlığın ve kültürel gelişmenin bir göstergesidir."

Okumanın kendisi bu denli önemliyken, okuma öğretimi de doğal olarak bireyin üretim sürecinde oldukça önemli bir yere sahip olacaktır.

Okuma öğretimi, Türk Dili dersi amaçları doğrultusunda öğrencilere anadilini doğru ve etkili kullanma becerisi kazandırmayı amaçlayan, anadili öğretimi kapsamındaki dört tümleşik beceriden en etkin olanıdır. Dil öğretimi girişik becerileri içerdiğinden okuma öğretimi ile ayrıca diğer dil becerilerinin de eşgüdümlü olarak gelişebileceği beklenmektedir. Bazı araştırmalar, okuma ve yazma becerisinin gelişiminde doğru orantı olduğunu göstermektedir. Smith (1989)'de belirtildiği gibi, okumayı okuma aracılığıyla öğreniyoruz; yazmayı yine okuma aracılığıyla öğreniyoruz.

Aksan (1993:202), anadilinin kullanımı ve anadili eğitimi konusunda, ilköğretimden yüksek öğretime kadar uzanan sorunlara ilişkin çözüm önerilerinden birini şöyle ifade etmektedir: "Sözlü ve yazılı anlatım konusuna gereken önem verilmeli, bu yolda gelişmeyi sağlayacak çok önemli bir etken olan okuma alışkanlığı yaratacak yöntemler uygulanmalı; çocuklara ve gençlere ders kitabı dışında okuma olanağı da yaratılmalıdır."

Sağlam bir anadilinin varlığı okuma-anlamayı kolaylaştırmakta; sürekli bir okuma etkinliği içinde olma da; sağlam, yetkin, etkili bir dil varlığına katkıda bulunmaktadır. Yani anadili yetisi ve okuma-anlama becerisi birbirini güdüleyen iki olgudur. $\mathrm{Bu}$ nedenledir ki dil becerilerini geliştirme amacını güden strateji çalışmaları (strategy training) nın önemli bir bölümü okuma ile ilgilidir.

Okuma öğretiminde büyük bir öneme sahip olan strateji kullanımı; okurların anlamı kavramadaki başarısızlıklarının ayırdına varmalarını, ne yapmaları gerektiğine karar vermelerini ve başarısızlığın üstesinden gelmek için bazı düzeltici, önleyici etkinlikler içine girmelerini sağlamaktadır (Baker and Brown, 1980:5).

Bireyin düşünsel ve duyuşsal gelişimini tamamlamasında okumanın, özellikle eleştirel okuma becerisinin rolü yadsınamaz. Öğrencilere bu becerinin kazandırılması için 
öncelikle okuma ediminin öğretilmesi ve sevdirilmesi gerekmektedir. Öğrencilerin okumayı sevmesi ve okuduklarından yararlanmaları, yani okumanın işlevsel olması, metinlerle kurulacak doğru ve yakın ilişkiye bağlı görünmektedir. Bu nedenle, doğru metin seçimi, metnin türüne yönelik beklenti oluşturma ve anlama-kavrama sürecinde metne nasıl yaklaşılacağının öğretimi diğer bir deyişle metin çözümleme (text analysing) bilgisi okuma öğretimindeki başarının önemli değişkenlerindendir.

Etkileşimsel Model'e işlerlik kazandıracak okuma stratejileri öğretimiyle ilgili olarak gerçekleştirilen bu deneysel çalışma, konusu itibariyle, iyi 'okur'lar yetiştirmeye; dolayısıyla çağdaş uygarlığın ve bilgi çağının gerektirdiği insan modelinin ölçütlerinden olan, anadilini doğru ve etkin kullanan; düşünen, sorgulayan, eleştirel düşünce düzeyine ulaşmış insan tipi yetiştirmeye katkıda bulunacağı düşünüldüğü için önemli görülmektedir. Bilgilendirici metinler, okurun bilgi evrenini genişletmek amaciyla bir konuda bilgi verme, ele alınan düşünceyi tartışma ve sorgulama yoluyla okura yaşama geçirebileceği bilgiler edindirmeyi amaçlar nitelikte içeriklendirilmektedir. Söz konusu insan tipinin yetişmesinde önemli bir işleve sahip olması nedeniyle, bu çalışmada bilgilendirici metin türü, özellikle ele alınmıştır.

Türkiye'de belli bir kuramsal bilgiyi, modeli ya da yöntemi temel alarak gerçekleştirilen uygulama çalışmalarının sayısı oldukça sınırlıdır. Etkileşimsel Model'e uygun okuma öğretiminin ele alındığı bu çalışma, deneysel bir çalışma olmakla birlikte, öğretim sürecinin kuramsal bilgiye dayalı olma niteliğini özenle değerlendiren bir çalışma olarak planlanmıştır. Bu çalışmada dilbilim (linguistics), metindilbilim (text linguistics) ve kullanımbilimsel (pragmatics) bulgulara dayandırılarak öğretilecek Etkileşimsel Model'e uygun stratejilerle, öğrencilerin bilgilendirici metinleri anlama, kavrama ve yorumlama sürecine katkıda bulunulması amaçlanmaktadır. Bu amacın da dilbilimdeki yeni eğilimlerin Türkiye'deki anadili öğretimine yansıtılmasına ve böylelikle anadili öğretiminin bilimsel yöntemlerle yapılmasına hizmet edeceği düşünülmektedir.

\section{4. Tanımlar}

Okuma : Bireyin, yazarın iletisini algılama ve ona tepki vermesini içeren zihinsel ya da bilişsel süreç (Keçik ve Uzun, 2002:127).

Anlama : Yazının ya da konuşmanın ne demek istediğini algılamaktır (Göğüş, 1978:71). Okuma Stratejisi : Okuma sırasında karşılaşılan sorunun giderilmesinde kullanılan teknikler (Baker and Brown, 1980:14).

İç Doğrultulu Model : Okuma ediminin harflerden başlayarak ses, sözcük, tümce ve metin düzlemine çıkan aşamalı bir süreç olduğunu benimseyen model (Keçik ve Uzun, 2002:127).

Dış Doğrultulu Model : Harf, ses ilişkisinden çok insanın sahip olduğu bilgi kaynaklarını ön plana çıkaran ve okumayı okurun kestirimlerinin yönlendirdiğini ileri süren model (Keçik ve Uzun, 2002:128).

Etkileşimsel Model : İç doğrultulu ve dış doğrultulu yaklaşımı birleştiren, anlamanın değişik bilgi kaynakları arasındaki etkileşimle gerçekleştiğini öne süren model (Keçik ve Uzun, 2002:129). 
Şema Modeli : Okurun sahip olduğu dünya bilgisinin; bilginin yorumlanmas1, alımlanması ve depolanması sırasında üslendiği işlevleri açıklamaya çalışan model (Keçik ve Uzun, 2002:131).

Geleneksel Yöntem : Bu çalışma bağlamında; 'etkileşimsel model'in kullanılmadığı, bilinen yöntemlerle sürdürülen öğretme-öğrenme etkinlikleri (Sever, 2000:277).

Öğretim : Öğrenmenin gerçekleşmesi ve bireyde istenen davranışların gelişmesi için uygulanan örgün süreçlerin tümüdür (Varış, 1981:21).

Deney Grubu : Okuma öğretiminin, Etkileşimsel Model uyarınca hazırlanan izlenceye göre yürütüldüğ̈̈ grup (Sever, 2000:277).

Kontrol Grubu : Okuma öğretiminin Etkileşimsel Model uyarınca hazırlanan izlenceye göre değil, varolan geleneksel yöntemler uyarınca sürdürüldüğü grup (Sever, 2000:277).

Erişi : Yetişeğe (öğretim programına) girişteki davranışlar (başarı 1) ile yetişekten çıkıştaki davranışlar (başarı 2) arasındaki hedeflerle tutarlı fark (Ertürk, 1982:115).

\section{5. Denenceler}

Çalı̧̧manın problem konusu ile ilgili alt problemler denencelerle şu şekilde yansıtılabilir:

Denence 1. "Türkçe öğretiminde Etkileşimsel Model'e uygun okuma öğretiminin gerçekleştirildiği deney grubunun okuduğunu anlama becerisinin 'kavrama' (comprehension) düzeyindeki erişi ortalaması ile geleneksel yöntemle öğretim yapılan kontrol grubunun okuduğunu anlama becerisinin 'kavrama' düzeyindeki erişi ortalaması arasında deney grubu lehine anlamlı fark vardır."

Denence 2. "Türkçe öğretiminde Etkileşimsel Model'e uygun okuma öğretiminin gerçekleştirildiği deney grubunun okuduğunu anlama becerisinin 'uygulama' (application) düzeyindeki erişi ortalaması ile geleneksel yöntemle öğretim yapılan kontrol grubunun okuduğunu anlama becerisinin 'uygulama' düzeyindeki erişi ortalaması arasında deney grubu lehine anlamlı fark vardır."

Denence 3. "Türkçe öğretiminde Etkileşimsel Model'e uygun okuma öğretiminin gerçekleştirildiği deney grubunun okuduğunu anlama becerisinin 'toplam' erişi ortalaması ile geleneksel yöntemle öğretim yapılan kontrol grubunun okuduğunu anlama becerisinin 'toplam' erişi ortalaması arasında deney grubu lehine anlamlı fark vardır."

\section{6. Sayılttılar}

Araştırma süresince görev alan öğretim görevlilerinin deneysel işlemin gereklerine uygun davranmış oldukları,

Deneklerin okuduğunu anlama becerisini ölçmeyi amaçlayan ölçeğin (ön testson test) geçerli ve güvenilir olduğu, olduğu,

Deneklerin ön test ve son test uygulamasında verdikleri yanıtların geçerli

Deneklere ön test ve son test uygulaması için verilen sürenin yeterli olduğu, çalışmamızın başlıca sayıltılarıdır.

\section{7. Sinirlılıklar}

$\mathrm{Bu}$ araştırma; 
Kapsam açısından; a) Dil öğretiminde yer alan dört tümleşik beceriden biri olan okuma öğretimiyle

b) Okuma edimini açıklayan Etkileşimsel Model'e uygun okuma yöntem ve teknikleriyle,

Amaçlar açısından; araştırmada belirtilen probleme ve ilgili alt problemlere yanıt bulunması ile,

Denekler açısından; Başkent Üniversitesi'nin Türk Dili dersi alan 1. sınıf öğrencileri ile,

Metin türü açısından; bilgilendirici metin türlerinden tartışmacı metin türü ile,

Uygulama süresi açısından; 2002-2003 öğretim yılı Güz döneminde on haftalık süre ile sinırlı tutulmuştur.

\section{YÖNTEM}

Metindilbilimin metin çözümlemede sunduğu araçlar kullanılarak gerçekleştirilen anadili öğretiminin, okuma-anlama edimi sürecine katkıda bulunacağı düşünülen bu çalışma, deneysel bir çalışma olarak planlanmıştır ve bu çalışmada deneysel model olarak, "Kontrol Gruplu Ön ve Son Test Modeli" kullanılmıştır.

\section{1. Deneklerin Seçimi}

Araştırma, Üniversite Seçme Sınavında aynı türden (eşit ağırlıklı), birbirine çok yakın puan alan, aynı fakültenin öğrencilerinden oluşan iki grup üzerinde gerçekleştirilmiştir. Deney ve kontrol gruplarında uygulamayı yürütecek öğretim elemanları cinsiyet ve mesleki kıdem açısından; öğrenciler ise sayıca denklenerek örneklem gruplarının denkliğinin sağlanmasına çalışılmıştır.

\section{2. Verilerin Toplanması}

Araştırmada saptanmış olan denencelerin sınanması için gerekli olan veriler, araştırmacı tarafından geliştirilen ve okuma becerisinin "kavrama" ve uygulama düzeyini ölçen, kısa yanıtlı yirmi sorudan oluşan "Okuduğunu Anlama Becerisi Ölçme Aracı" ile elde edilmiştir.

Ölçme aracı, deney ve kontrol grubu öğrencilerinin tümüne ön ve son test şeklinde, deneysel işlemin başında ve sonunda olmak üzere iki kez uygulanmıştır.

\section{3. İşlem Basamakları}

$\mathrm{Bu}$ süreci; hazırlık, uygulama ve sonuçların değerlendirilmesi olarak sınıflandırarak açıklamaya çalışalım:

\section{Hazırlık evresinde;}

Öncelikle çalışmanın amacına uygun olarak öğrencilere kazandırılmak istenen davranışlar belirlenmiştir. Başlangıçta 15 adet olarak belirlenen davranış sayısı, konu uzmanlaıyla ${ }^{1}$ tartışılarak, ölçülemeyecek olanlar ve birbiriyle örtüşenler elenerek 10 'a

1 Prof. Dr. Cahit Kavcar, Prof. Dr. Sedat Sever, Doç.Dr. Leyla Uzun 
indirilmiştir. Davranışlar, denencemiz dikkate alınarak kavrama ve uygulama düzeyinde tutulmaya çalışılmıştır.

Daha sonra, deneysel sürecin başında ve sonunda uygulanacak olan ve bu davranışları ölçmeyi amaçlayan ölçme aracı geliştirilmiştir.

$\mathrm{Bu}$ aşamada önce ölçek için uygun iki metin seçilmiştir. Ölçme değerlendirme uzmanlarının $^{2}$ önerileriyle, bu metinlerin zorluk ve uzunluk açısından denk olmasına dikkat edilmiş ve sorular, ölçmenin güvenilirliği açısından, yanıtları olabildiğince net olacak şekilde (açık uçlu olmayacak şekilde) düzenlenmeye çalışılmıştır.

Ölçme aracının hazırlanması, geliştirilmesi ve uygulanması için yapılan işlemler şunlardır:

Konu uzmanlarının önerileriyle seçilen metinler ve Etkileşimsel Model'e uygun içeriğe dayandırılarak hazırlanan 45 soruluk ölçme aracı taslağı, konu uzmanlarının görüş, eleştiri ve önerileri doğrultusunda, ölçmeye konu olan her davranışı yoklamaya yönelik üçer soru olmak üzere 30 sorudan oluşacak şekilde yeniden düzenlenmiştir.

Veri toplama yönteminin geçerliliğini ölçmek ve ölçme aracının güvenilirliğini sağlamak amacıyla deney ve kontrol grupları dışında on iki kişiden oluşan bir başka grup öğrenci (Amerikan Dili ve Edebiyatı Bölümü I. Sınıf öğrencileri) üzerinde ön deneme yapılmıştır. Ölçme aracı, ön deneme sonuçlarının ilgili uzmanlarca değerlendirilmesi sonrasında 20 sorudan oluşmak üzere son şeklini almış; daha sonra deney ve kontrol grupları üzerinde uygulanmıştır.

Ölçeği değerlendiren uzmanların verdikleri puanların güvenirliği varyans analizine dayalı güvenirlik yöntemi ile hesaplanmıştır (ANOVA testi). Buna göre, deney grubuna ait ön test ve son test güvenirlikleri 0.90 ve 0.94 ; kontrol grubuna ait ön test ve son test güvenirlikleri 0.98 ve 0.99 olarak bulunmuştur. $\mathrm{Bu}$ değerler anılan ölçme aracının güvenirliğinin yeterli ölçüde yüksek olduğunu göstermiştir. (Güvenilirlik testinde bu sonucun alınması, denencelerin doğrulanmasında kullanılan istatistiksel işlemler sırasında $\mathrm{A}, \mathrm{B}, \mathrm{C}$ konu uzmanlarının verdikleri puanların ortalamaları üzerinden işlem yapılabilmesine olanak sağlamıştır.)

Sekiz hafta süren öğretim süreci sonunda, öğretim öncesi ön test olarak uygulanan ölçme aracı, hiç bir değişiklik yapılmaksızın son test olarak tekrar uygulanmıştır. Hazırlık aşamasının ölçek kadar önemli bir diğer konusu, Eğitim Durumları'nın hazırlığıdır. Belirlenen davranışları kazandırmaya yönelik ders planları, dört ayrı eğitim durumu olarak hazırlanmıştır. Ana nokta ve yardımcı noktalar, her ders için, davranışların aşamalılık ve ardışıklık özelliği de göz önünde bulundurularak belirlenmiştir.

Eğitim durumlarının söz konusu modeli etkin kılacak çok sayıda okuma stratejisini içerecek şekilde düzenlenmesine özen gösterilmiştir. Model, çağdaş eğitbilimin öngördüğü biçimde öğrenci odaklı bir model olup öğrencinin anlamlandırma sürecine etkin katılımını öngörmektedir. Bu nedenle ders planları; ön bilgileri çağırma, biçimsel düzenlenişi değerlendirme, soru sorma, bir sonraki bölümle ilgili tahminde

2 Prof. Dr. Süleyman Çetin Özoğul, Prof. Dr. Yaşar Baykul, Prof.Dr. Ezel Tavşancıl 
bulunma ve bu tahminleri denetleme, bilgiyi tekrar, kavram ve bilgi haritaları oluşturma, özetleme, yorum getirme gibi bilişsel süreçlerle öğrencinin bilincinin uyanık olmasını ve kendi okumasını yönlendirmesini amaçlayacak şekilde hazırlanmaya çalışılmıştır. Her planın sonunda amaç davranışların kazandırılmasını denetleyen değerlendirme soruları yer almıştır.

Eğitim durumları önce, araştırmacıya ait bir başka grup öğrenci (İletişim Fakültesi I. sınıf öğrencileri) üzerinde denenmiştir. Bu ön deneme; sürenin uygunluğu, amaçlanan davranışların kazandırılması, öğrenci katılganlığ 1 vb. değişkenler göz önünde bulundurularak araştırmacı ile konu uzmanları tarafından hafta içinde değerlendirilmeye alınmıştır. Ders planları son şeklini aldıktan sonra, deney grubu üzerinde, Yazılı Anlatım dersi kapsamında uygulamaya konulmuştur.

\section{İstatistiksel İşlem Basamakları}

Çalışmanın denencelerinin sınanması amacıyla ortalamalar üzerinden yapılan t-testleri öncesinde, bilgi kaybını önleyerek daha sağlıklı sonuçlara ulaşabilmek için; A, B ve C konu uzmanlarının verdiği ham puanlar üzerinden bazı bağımlı ve bağımsız grup karşılaştırmaları yapılmıştır. Bunlar sırasıyla şöyledir:

1. Öncelikle, Deney ve Kontrol grubundaki deneklere verilen ön ve son testi değerlendiren $\mathrm{A}, \mathrm{B}$ ve $\mathrm{C}$ konu uzmanlarının ön ve son test puanlarına ilişkin parametrik testlerin (t-testi, ANOVA-varyans analizi) kullanılabilmesi için sağlanması gereken "normal dağılıma uygunluk" test edilmiş (Kolmogorov-Simirnov testi ile), p değerleri 0.05 'ten büyük olduğu için normal dağglıma uyum, \% 95 güven düzeyinde anlamlı bulunmuştur. Bunun yanısıra t-testi ve ANOVA için "varyansların homojenliği-eşitliği varsayımının da sağlanması gerekmektedir. Bu amaçla Levene testi kullanılmıştır. Bunun sonucunda, denencelerin sinanması amaciyla deney ve kontrol grubu puanlarının karşılaştırılmasında t-testi kullanılması uygun görülmüş̧ür.

2. Bağımsız iki örneklem karşılaş̧ırması olarak; A, B, C konu uzmanlarının deney ve kontrol grubuna verdiği ön-test puanları karşılaştırılmıştır. Her üç karşılaştırma için varyansların eşitliği Levene testi ile test edildikten sonra, ( $p$ olasılık değerleri 0.05 'ten büyük olduğu için varyanslar eşittir) t-testi kullanılmıştır. Deney A ile Kontrol A arasındaki fark anlamlı çıkarken, Deney B ile Kontrol B ve Deney C ile Kontrol C arasındaki farklar anlamlı çıkmamıştır.

$\mathrm{Bu}$ sonuç, her iki grubun ön test puanları arasında, yani uygulama başlangıcında deney ve kontrol grubu arasında büyük ölçüde anlamlı fark olmadığını, örneklemlerin homojen gruptan seçilmiş olduğunu göstermiştir.

3. Bağımsız iki örneklem karşılaştırması olarak; A, B, C konu uzmanlarının deney ve kontrol grubuna verdiği son-test puanları, ön test puan karşılaştırmasında izlenen yöntemle karşılaştırılmıştır. Sonuçta, deney ve kontrol grubu için son test puanları 
açısından, her üç uzmanın verdiği puanlar arasında \% 95 güven düzeyinde anlamlı fark olduğu görülmüştür. Ön testlerinden yakın puanlar alan iki grup, son testlerde anlamlı farklılık göstermiş̧ir.

$\mathrm{Bu}$ sonuca göre, denek ve değerlendiriciler değişmediği için, farkın uygulanan modelden kaynaklandığı söylenebilir.

4. Deney ve Kontrol grubu için A, B, C konu uzmanlarının ön ve son testlere verdiği puanlar açısından, konu uzmanı sayısının ikiden çok olması nedeniyle ANOVA kullanılarak, aşağıdaki karşılaştırmalar yapılmıştır:
A. Deney grubu ön test
B. Deney grubu son test
C. Kontrol grubu ön test
D. Kontrol grubu son test

(Örneğin, deney grubunun ön testlerine A'nın, B'nin C'nin verdiği puanların karşılaştırılması gibi.) Her üç konu uzmanının aynı tür teste verdiği puanlar karşılaştırıldığında; deney grubu ön test ile kontrol grubu ön test ve kontrol grubu son test puanları açısından istatistiksel olarak anlamlı fark bulunmazken, deney grubu son test puanları açısından üç konu uzmanı arasında farklı1ık bulunmuştur. $\mathrm{Bu}$ farklı1ığın araştırılmasında Tukey HSD testi kullanılmıştır. Buna göre, deney grubu için son test puanları açısından A ve C konu uzmanı arasında fark varken, A-B ve B-C uzmanları arasında fark olmadığı sonucuna ulaşılmıştır.

Uç değer sayılabilecek bir gözlem (kontrol grubundaki 20. gözlem-denek) A, B ve C'nin son test puanları için yapılan değerlendirmeden çıkarılarak işlem tekrarlanmış; ancak A, $\mathrm{B}, \mathrm{C}$ değerlendirmeleri arasında \% 95 güvenle yine anlamlı bir fark bulunmamıştır.

5. Bağımlı iki örneklem karşılaştırması olarak; A, B, C konu uzmanlarının, deney ve kontrol grubu kendi içinde olmak üzere, ön ve son test puan farkları ayrı ayrı karşılaştırılmıştır. Öncelikle bu fark puanlarına ilişsin normal dağılıma uygunluk testi (Kolmogorov-Simirnov) yapılmıştır. Normal dağılıma uyum anlamlı bulunmuştur. Deney grubunda ön ve son test puan farkları A, B, C değerlendiricileri için önemli çıarken; kontrol grubunda yalnız B değerlendiricisi için önemli, A ve C değerlendiricileri için önemsiz bulunmuştur.

6. Denencelerin sinanması amaciyla ortalama puanlar üzerinden deney ve kontrol grupları okuduğunu anlama becerisi "kavrama", "uygulama" düzeyi ve "toplam" karşılaştırmaları (t-testi kullanılarak) yapılmıştır. Önce deney ve kontrol grubu ön testleri karşılaştırılmıştır. İki grubun ön test puanları arasında her üç düzeyde anlamlı fark olmadığ sonucuna ulaşılmıştır.

7. Son olarak deney ve kontrol gruplarının okuduğunu anlama becerisi "kavrama", "uygulama" ve "toplam" düzeyde erişi karşıllaştırmaları (t-testi kullanılarak) yapılmıştır. Erişi puanları (ön test - son test farkı) karşılaştırmaları sonucunda, istatistiksel olarak, iki 
grup arasında "kavrama" düzeyinde anlamlı bir fark bulunmamış, "uygulama" düzeyinde ve "toplam" erişide deney grubu lehine anlamlı fark bulunduğu sonucuna ulaşılmıştır.

\section{BULGULAR}

Denencelerin sınanması amaciyla ortalama puanlar üzerinden deney ve kontrol grupları okuduğunu anlama becerisi "kavrama", "uygulama" düzeyi ve "toplam" karşılaştırmaları (t-testi kullanılarak) yapılmıştır.

Önce deney ve kontrol grubu ön testleri karşılaştırılmıştır. İki grubun ön test puanları arasında her üç düzeyde anlamlı fark olmadığı sonucuna ulaşılmıştır:

Tablo 1: Deney ve Kontrol Gruplarının Okuduğunu Anlama Becerisi Ön Test "Kavrama” Düzeyi Puanlart

\begin{tabular}{lcccc} 
& & Ön Test & Ön Test & Gözlenen \\
& $\boldsymbol{N}$ & $\bar{X}$ & $\mathrm{~S}$ & $\mathrm{t}$ \\
\hline Deney Grubu & 29 & 30.99 & 8.28 & 1.66 \\
Kontrol Grubu & 26 & 27.47 & 7.52 & \\
\hline
\end{tabular}

$\mathrm{p}=0.10>0.05$

Tablo 1'e göre deney grubunun ön test kavrama düzeyi puanları ortalamas1 30.99, kontrol grubunun ise 27.47 'dir. Deney ve kontrol grupları ön test kavrama düzeyi puanları arasında anlamlı bir farkın olup olmadığı t-testi ile yoklanmıştır. Gözlenen fark .05 düzeyinde anlamlı bulunmamıştır.

$\mathrm{Bu}$ verilere göre, deney ve kontrol gruplarının Okuduğunu Anlama Becerisi Ön-Test "kavrama" düzeyi puanları açısından denk olduğu söylenebilir.

Tablo 2: Deney ve Kontrol Gruplarının Okuduğunu Anlama Becerisi Ön Test "Uygulama” Düzeyi Puanları

\begin{tabular}{lcccc} 
& & Ön Test & Ön Test & Gözlenen \\
& $N$ & $\bar{X}$ & $\mathrm{~S}$ & $\mathrm{t}$ \\
\hline Deney Grubu & 29 & 11.91 & 6.4 & 1.81 \\
Kontrol Grubu & 26 & 9.15 & 4.9 & \\
\hline
\end{tabular}

$\mathrm{p}=0.07>0.05$ 
Tablo 2'ye göre deney grubunun ön test uygulama düzeyi puanları ortalamas1 11.91, kontrol grubununki ise $9.15^{\prime}$ tir. Deney ve kontrol grupları ön test uygulama düzeyi puanları arasında anlamlı bir farkın olup olmadığı t-testi ile yoklanmıştır. Gözlenen fark .05 düzeyinde anlamlı bulunmamıştır.

$\mathrm{Bu}$ verilere göre, deney ve kontrol gruplarının Okuduğunu Anlama Becerisi Ön-Test "uygulama" düzeyi puanları açısından denk olduğu söylenebilir.

Tablo 3: Deney ve Kontrol Gruplarının Okuduğunu Anlama Becerisi Ön Test "Toplam" Puanlart

\begin{tabular}{lcccc} 
& & Ön Test & Ön Test & Gözlenen \\
& $\boldsymbol{N}$ & $\bar{X}$ & $\mathrm{~S}$ & $\mathrm{t}$ \\
\hline Deney Grubu & 29 & 42.9 & 13.5 & 1.90 \\
Kontrol Grubu & 26 & 36.6 & 11.0 & \\
\hline
\end{tabular}

$\mathrm{p}=0.06>0.05$

Tablo 3'e göre deney grubunun ön test uygulama düzeyi puanları ortalaması 42.9, kontrol grubununki ise 36.6 'dır. Deney ve kontrol grupları ön test toplam puanları arasında anlamlı bir farkın olup olmadığı t-testi ile yoklanmıştır. Gözlenen fark .05 düzeyinde anlamlı bulunmamıştır.

$\mathrm{Bu}$ verilere göre, deney ve kontrol gruplarının Okuduğunu Anlama Becerisi Ön-Test "toplam" puanları açısından denk olduğu söylenebilir.

Daha sonra deney ve kontrol gruplarının "kavrama" düzeyi erişi ortalamaları arasında anlamlı bir farkın olup olmadığı t-testi ile yoklanmıştır.

Tablo 4:Deney ve Kontrol Gruplarının Okuduğunu Anlama Becerisi "Kavrama” Düzeyi Erişileri

\begin{tabular}{lcccc} 
& $\mathrm{N}$ & $\bar{X}$ & $\mathrm{~S}$ & $\begin{array}{c}\text { Gözlenen } \\
\mathrm{t}\end{array}$ \\
\hline Deney Grubu & 29 & 7.37 & 8.59 & 1.90 \\
Kontrol Grubu & 26 & 2.50 & 10.4 & \\
\hline
\end{tabular}

$p=0.06>0.05$ 
Tablo 4'e göre, Etkileşimsel Model'in kullanıldığı deney grubunun Okuduğunu Anlama Becerisi "kavrama" düzeyi erişi ortalaması 7.37, geleneksel yöntemin kullanıldı̆̆1 kontrol grubunun "kavrama" düzeyi erişi ortalaması ise 2.50 'dir. Deney ve kontrol gruplarının erişi ortalamaları arasında anlamlı bir farkın olup olmadığı t-testi ile yoklanmıştır. Gözlenen fark .05 düzeyinde anlamlı bulunmamıştır. (Az bir farkla, alfa 0.7 düzeyinde bakıldığında, fark istatistiksel olarak anlamlı görünecektir.)

Tablo 5: Deney ve Kontrol Gruplarının Okuduğunu Anlama Becerisi "Uygulama" Düzeyi Erişileri

\begin{tabular}{lcccc}
\hline & & & & Gözlenen \\
& $\mathrm{N}$ & $\bar{X}$ & $\mathrm{~S}$ & $2.30^{*}$ \\
\hline Deney Grubu & 29 & 4.97 & 4.90 & \\
Kontrol Grubu & 26 & 1.97 & 4.75 & \\
\hline
\end{tabular}

$\mathrm{p}=0.02<0.05$

$\mathrm{Bu}$ verilere göre, okuduğunu anlama becerisinin "kavrama" düzeyindeki davranışlarını kazandırmada, Etkileşimsel Model'e uygun yöntem ile geleneksel yöntemin aynı derecede etkili olduğu söylenebilir.

Tablo 5'e göre, Etkileşimsel Model'in kullanıldığı deney grubunun Okuduğunu Anlama Becerisi "uygulama" düzeyi erişi ortalaması 4.97, geleneksel yöntemin kullanıldığ1 kontrol grubunun "uygulama" düzeyi erişi ortalaması ise 1.97'dir. Deney ve kontrol gruplarının erişi ortalamaları arasında anlamlı bir farkın olup olmadığ $1 \mathrm{t}$-testi ile yoklanmıştır. Gözlenen fark .05 düzeyinde anlamlı bulunmuştur.

$\mathrm{Bu}$ verilere göre, Etkileşimsel Model'in; öğrencilere, okuduğunu anlama becerisinin "uygulama" düzeyindeki davranışlarını kazandırmada, "geleneksel yöntem"den daha etkili olduğu söylenebilir. Son olarak deney grubu ile kontrol grubunun "Toplam" (kavrama+uygulama) erişi ortalamaları yine t-testi ile karşılaştırılmıştır.

Tablo 6: Deney ve Kontrol Gruplarının Okuduğunu Anlama Becerisi "Toplam (Kavrama + Uygulama)" Erişileri

\begin{tabular}{lcccc} 
& $\mathrm{N}$ & $\bar{X}$ & $\mathrm{~S}$ & $\begin{array}{c}\text { Gözlenen } \\
\mathrm{t}\end{array}$ \\
\hline Deney Grubu & 29 & 12.3 & 12.0 & $2.39^{*}$ \\
Kontrol Grubu & 26 & 4.4 & 12.5 & \\
$\mathrm{p}=0.02<0.05$ & & & &
\end{tabular}


Tablo 6'ya göre, Etkileşimsel Model'in kullanıldığı deney grubunun Okuduğunu Anlama Becerisi "toplam" erişi ortalaması 12.3, geleneksel yöntemin kullanıldığı kontrol grubunun "toplam" erişi ortalaması ise 4.4'dür. Deney ve kontrol gruplarının erişi ortalamaları arasında anlamlı bir farkın olup olmadığ t-testi ile yoklanmıştır. Gözlenen fark .05 düzeyinde anlamlı bulunmuştur.

Bu verilere göre, Etkileşimsel Model'in; öğrencilere, okuduğunu anlama becerisini bütünleyen davranışların kazandırılmasında, geleneksel yöntemden daha etkili olduğu söylenebilir.

\section{TARTIŞMA}

Araştırmanın bu bölümünde, sınanan denenceler yorumlanmış, bulgular ışığında aşağıdaki vargılara ulaşılmıştır:

Denence 1: Denence 1 bulgular tarafından doğrulanmamıştır. Bu sonuç şöyle yorumlanabilir:

$\mathrm{Bu}$ araştırmada kazandırılması hedeflenen davranışların okuduğunu anlama becerisi düzeylerine göre dağılımı incelendiğinde, kavrama düzeyine alınan davranışların uygulama düzeyi davranışlarına göre daha çok metnin yüzey yapısında varolan dilseldilbilgisel ilişkilerle ilgili olduğu görülür. Örneğin anahtar sözcükler, sözcük anlamlandırma, bağlaşıklık öğeleri, konuda sıralılık vb. Etkileșimsel Model etkin bir okuma modelidir ve anlamlandırmanın, metnin yüzey yapısından hareketle derin yapıya, yani anlama ulaşmakla; bunun için de metin tabanındaki görünür dilsel öğeleri ve onların ilişkilerini algılayıp dünya bilgileriyle etkileşime sokmakla gerçekleşeceğini öngörür. Geleneksel yöntem, zaten daha çok metnin yüzey yapısıyla ilgilenmektedir. Bu nedenle (seçilen davranışlar bağlamında) uygulama becerisine göre daha biçimsel ve yüzeysel sayılabilecek olan kavrama düzeyi becerilerinde geleneksel yöntem etkileşimsel yöntem kadar etkili olmuş olabilir.

Denence 2: "Uygulama" düzeyindeki erişi ortalamasında deney grubu lehine fark olduğu savını içeren Denence 2 bulgular tarafından doğrulanmıştır. Bu sonuç şöyle yorumlanabilir:

Yazarı yazmaya iten, iletişimsel amacı, yani metnin ana iletisi metnin üst yapısını oluşturur. Bu çalışmada ele alınan bilgilendirici metinlerin sözbilimsel yapıları göz önünde bulundurulduğunda metne giren tüm öğelerin bir iddia yapısı şemsiyesi altında biçimlendiği görülür. Metni anlamaya yönelen okurun ulaşacağı son nokta, metnin en kısa özeti diyebileceğimiz "ana ileti” dir. Aynı şekilde, bir alt düzeyde, okuduğunu anlamış olmanın bir önemli göstergesi de okurun metni; silme, seçme, genelleme ve 
yeniden kurma gibi bir dizi işlemden sonra kendi tümceleriyle özetleyebilmesidir. Bu iki eylem üst düzey bilişsel işlemler gerektirmektedir.

$\mathrm{Bu}$ çalışma çerçevesinde oldukça önemli bir yere sahip olan bu iki davranış, uygulama düzeyine alınmıştır. Özetleme ve ana iletiyi bulma, okuma öğretimi bağlamında kavrama düzeyine alınan davranışların öncelikle kazandırılmış olmasını gerektirmektedir.

Denence 3: Her iki düzey becerinin "toplam" erişi ortalaması arasında, Etkileşimsel Model grubu öğrencilerinin lehine anlamlı fark olduğu savını içeren Denence 3 bulgular tarafından doğrulanmıştır. Bu sonuç şöyle yorumlanabilir:

Okuduğunu anlama becerisinin toplam erişi ortalaması, kavrama ve uygulama düzeylerindeki davranışların toplamından oluşmaktadır. Deney grubu toplam erişi ortalamasının kontrol grubuna göre anlamlı düzeyde farklı çıkması; Denence 1 ve özellikle Denence 2'de belirtilen değişkenlerin toplam erişiyi de etkilemiş olmasıyla açıklanabilir.

Etkileşimsel Model'e uygun olarak hazırlanan eğitim durumları ile öğrencilerin sadece metin yüzeyindeki bilgilerle yetinmeyip üst düzey sorular aracılığıyla temel iletiye ulaşması amaçlanmıştır. Okuma öncesi, okuma süreci ve okuma sonrasında anlamayı sağlayacak ve güçlendirecek stratejiler öğretilmiştir. Metinle doğrudan etkileşime geçmeden önce, okuma öncesi çalışmalarla ön bilgiler çağrılıp etkin hale getirilmeye çalışılmıştır. Okuma esnasında düşüncelerin eklemlenmesi sırasında kullanılan işaretleyicileri ve onların ilişkilerini değerlendirmeleri, sözcükleri bağlamından yararlanarak anlamlandırmaları, önemli ya da ayrık bilgiyi ayırt etmeleri istenmiştir. Soru sorma, tahminde bulunma, onaylama ya da karşı çıkma, tekrar vb. zihinsel süreçleri etkin kılacak stratejileri farkında olarak kullanmaları, böylece kendi okumalarını yönetmeleri sağlanmaya çalışılmıştır.

Başlangıçta, stratejiler öğrenilene ve strateji kullanımında belirli bir hız kazanılana kadar, bir sonraki aşamada yapılacakların düşünülmesi ve planlanmasının, yani ilke edinme sürecinin süre kaybına neden olduğu düşünülebilir. Ancak, beyin böylesi işlemler için koşullandığında, bilişsel bir süreç olarak daha sonraki okumaların daha hızlı ve etkin olması sağlanabilecektir. Öğretim süresinin daha uzun tutulması ve bilişsel öğrenmenin devamlılığ

\section{ÖNERILLER}

Anadili dersinin çok yönlü ve girişik nitelikli oluşu, bilgiden çok beceri ve alışkanlık geliştirmeyi amaçlaması; Türkçe öğretiminde öğrencilere istenilen öğrenme yaşantılarının kazandırılabileceği etkili eğitim durumlarının seçilip düzenlenmesi işini 
daha da önemli kılmaktadır. Türkçe derslerinde, öğretim programlarında amaçlanan davranışların her bir öğrenciye kazandırılması, uygulanagelen geleneksel öğretim yöntemlerinde yenilikler ve değişiklikler yapmayı ya da yeni öğretme-öğrenme modellerini kullanmayı gerektirmektedir (Sever, 2000).

Dil öğretimiyle ilgili bu gerçekliğin ve bu araştırmadan elde edilen bulguların 1şı̆̆ında okuma öğretimine ilişkin şu önerilerde bulunulabilir.

\subsection{Okuma Öğretiminin İçeriği ve Yöntemlerine İlişsin Öneriler}

a) Yeni izlenceler ve yöntemler öğrencilerin derse olan ilgisini artırmaktadır. Dil öğretiminde kullanılan çağdaş yaklaşımlar izlenmeli ve anadil öğretimi izlenceleri bu çerçevede hazırlanmalıdır.

b) Bilişsel öğrenme stratejileriyle okuma stratejileri arasında yakın ilişki olduğu gözlemlenmiştir. Öğretimin her alanında (tüm alan derslerinde) ezberden uzak, bilişsel ve etkileşimsel yöntemlerin uygulanması sağlanmalıdır. Öğretimin ilk yıllarından başlayarak öğrencilerin okuduğunu anlama becerisi; öncelikle kavrama ve uygulama ve sonrasında da üst düzey bilişsel işlemler olarak analiz, sentez ve değerlendirme düzeyindeki becerileri geliştirecek şekilde planlanmalıdır. Öğretimin genel çerçevesi ilk basamaktan, ilkokuldan başlayarak; bilgiyi işlemleme, yani yeni bilgiyi eski bilgiyle ilişkilendirme, amaçlı öğrenme, bilgiyi sorgulama, yorumlama, eleştirme gibi bilişsel bir temelde çizilmeli ve öğretim buna uygun yöntemlerle gerçekleştirilmelidir. Bu amaca dönük strateji öğretimine öğrencilerin düzeylerine uygun programlarla ilkokul yıllarından başlanabilir.

c) Ayrıca öğrenciler Türkçe dersleri başta olmak üzere, diğer derslerde de alanla ilgili destekleyici kitaplar okumaya özendirilmelidir.

d) Okuma öğretiminde, parçadan bütüne yaklaşımı öğrenci katılımını artırmaktadır. Öğrencilerin daha küçük dilsel birimlerden hareketle, soyutlama yaparak bilgiye ve genel yargılara kendilerinin ulaşmaları, böylece okuma sürecine daha etkin katılımları sağlanmalıdır. Dilbilgisi ve sözcük öğretimi soyut ve kuramsal bilgi kazandırma öğretimi olmaktan çıkarılıp işlevsel hale getirilmelidir. Örneğin; adılların, bağlaçların bağlaşıklık öğeleri olarak işlevleri, metin inceleme çalışmaları kapsamında uygulamalarla öğretilmelidir. Aynı şekilde tümce öğeleri bilgisi, uzun ve karmaşı metin birimlerini anlamlandırma sırasında, metni anlamlı parçalara bölerek anlamayı kolaylaştırmanın aracı olarak öğretilebilir.

e) Metin türü ve yapısı (metnin iletişim amacı, metne özgü sözbilimsel yapılar, dil kullanımı vb.) konusunda bilgilendirilmiş, metinle ilgili beklenti oluşturulmuş 
öğrencilerin metnin derin yapısına ulaşabilmeleri daha kolay olmaktadır. Bu nedenle okuma çalışması öncesinde metin türleri ve sözbilimsel yapıları hakkında ön bilgilendirme yapılmalı metne yaklaşım konusunda bilinç oluşturulmalıdır.

f) Dil öğretimi girişik becerileri içermektedir. Dört becerinin (okuma, yazma, dinleme, konuşma) hepsi birbirini etkilemekle birlikte, okuma becerisinin diğerleri için bir ön koşul olduğu düşünülebilir. Bu nedenle dil öğretiminde okuma becerisi ayrı bir öneme ve önceliğe sahip k1lınabilir.

g) Okuma ve yazma konusunda yapılan deneysel çalışmaların verileri ışığında yüksek öğretimdeki Türk dili dersleri çerçeve programları yeniden gözden geçirilerek genişletilmelidir. Türkçe öğretimi programlarının hazırlanmasında, anadili ve yabancı dil öğretimi sürecindeki (özellikle okuma ediminde) benzerlikler nedeniyle, yabancı dil öğretiminde kullanılan yöntem ve tekniklerle ilgili olarak yapılan çok sayıda araştırmanın bulgularından da yararlanılmalıdır.

\section{2. Yapılabilecek Çalışmalara İlişskin Öneriler:}

a) Öğretimin çeşitli kademelerindeki strateji kullanımı ile üniversite düzeyinde okuma anlam becerisinin ilișkisini araștıran çalıșmalar yapılabilir.

b) Metinlerin güçlük derecesine göre, okuma becerisini çeşitli düzeylerde ölçen metin temelli çalışmalar yapılabilir.

c) Bu çalışmaya konu olan Etkileşimsel Model'in bileşenlerinden olan, bireylerin

belli bir alanda sahip oldukları artalan bilgilerinin veya sosyo-kültürel tabanlarının vb. etkenlerin okuma anlama düzeyiyle ilişkisini araştıran çalışma yapılabilir. yapilabilir

d) Okuma stratejileri kullanımının, bilginin kalıcılığına etkisini araştıran çalışma

e) Okuma stratejilerinin her birini ayrı ayrı ya da birkaçını birlikte ele alan çalışmalar yapılabilir.

f) Farklı dil düzeylerine ve becerilerine sahip kişilerle, dil düzeyi veya söz varlıği ile

okuma-anlama ilişkisini araştıran çalışmalar yapılabilir. öğretimiyle

g) Sözbilimsel yap1 (retorik) öğretimi benzeri metin kurucu öğelerin okuma-anlama ilişkisini araştıran çalışmalar yapılabilir. yapılabilir.

h) Okuma becerisiyle yazma becerisinin ilişkisini araştıran çalışmalar

KAYNAKÇA

Aksan, D. “Anadili Eğitimi” VII. Dilbilim Kurultayı Bildirileri, A.Ü. Dil ve 
Tarih Coğrafya Fak.Yayını, Ankara, 1993.

Armbruster, B.B., "Does Text Structure/Summarization Instruction Facilitate Learning from Expository Texts?" Reading Research Quarterly, 22, s.331-346, 1987.

Ataç, N. "Aramak, Bulmak” Günce, İstanbul, 1972.

Baykul, Y., Eğitimde ve Psikolojide Ölçme. ÖSYM Yayınları, Ankara, 2000.

Baker, L.and Brown, A.L. Metacognitive Skill and Reading. ( Technical report No:188).

Urbana Campain: Center for the Study of Reading, University of Illinois, 1980.

Beaugrande, R. de/ W.Dressler. Introduction to Text Linguistics Essex:Longman, Tubingen, 1981.

Biber, D. "A Typology of English Texts" : Linguistics, 1989.

Binyazar, A. "Anadili Öğretiminde Yazınsal Alanlara Açılım” Türk Dili, Dil Öğretimi Özel Sayısı. TDK, Ankara, s.18, 1983.

Block, E.L. "See How They Read: Comprehention Monitoring of L1 and L2 Readers" TESOL Quarterly, 26-2, s. 319-343, 1992.

.The Comprehension Strategies of Second Language Readers, TESOL Quarterly, 1986.

Brown, G. and G.Yule. Discourse Analysis. Cambridge University Press, Cambridge: 1983.

Burns, P.C., B.O.Roe, and E.P.Ross. Teaching Reading in Today”s Elementary Schools. Houghton Mifflin Conpany, Boston: 1988.

Carell, P.L. 1983 a. "Three Components of Background Knowledge in Reading Comprehension". Language Learning . 33 (2): s.183-207, 1983. . 1983b. "Background Knowledge in Second Languange

Comprehention" Language Learning and Communication. 2(1) s.25-34, 1983. . 1983 c. "Some Issues in Studying the Role of Schemata or

Background Knowledge" Paper Presented at the 17 th Annual TESOL Convention, Toronto, Canada, March, 1983.

Carell, P.L. and Eisterhold J.C. "Schemata Theory and ESL Reading Pedagogy". TESOL Quarterly. s.553-573, 1983.

Celce-Murcia. Discourse Analysis and Grammar Instruction. Annual Review of Applied Linguistics, 1990.

Cook, G. Discourse. Hong Kong: Oxford University Press, 1979.

Collier, "Age and rate of acquisition of second language for academic purposes" TESOL Quarterly, 21, 617-641.

Çekiç, H. "Effects of Prior Knowledge of Content and Rhetorical Structures on EFL Learner"s Reading Comprehension”. Yayımlanmamış Doktora Tezi. Eskişehir: Anadolu Ü. Sos. Bil. Ens. 1999.

Çelik, J. "Dil Öğretiminde Okuma - Anlama Stratejileri” Dilbilim Araştırmaları 1998. Ankara, 1998.

Davies, F. Introducing Reading. London: Penguin Books Ltd., 1995.

Day, R. New Ways in Teaching Reading. Bloomington: Pantagraph Printing, 1993.

Demircan, Ö. Yabancı Dil Öğretim Yöntemleri. İstanbul: Erkin Eğitim Yayıncılık, 1990 
Denkel A. Anlaşma: Anlatma ve Anlama (İletişim Üzerine Bir Felsefe Anlatımı). İstanbul:Boğaziçi Ü.Yay., 1981.

Dijk, T. A.van. Macro Structures. New Jersey: Lawrence Erlbaum, 1980.

Dijk, T.A. and W. Kintsch . Strategies of Discourse Comprehention . London Academic Press. 1983.

Ecevit, Y. Orhan Pamuk'u Okumak. İstanbul: Gerçek Yayınevi, 1996.

Emeksiz, E.Z. "Yabancı Dil Öğrenimi Sürecinde Yer Alan Metin Okuma ve Anlama

Derslerinde Metin Okur Etkileşiminde Öğretmenin Rolü: Soru Sorma Teknikleri ve Etkililiğin Ölçülmesi” Eskişehir: Anadolu Ü. Proje Fonu, 1999.

Ertürk, S . Eğitimde Program Geliştirme. Ankara: 1982.

Ellis, G. and Sinclair, B. Learning to Learn English. Cambridge University Press, 1989.

Göğüş, B. “Anadili Eğitim Programlarının Niteliği” Türk Dili, Dil Öğretimi Özel Sayısl, Ankara: TDK, s.40 1983.

Orta Dereceli Okullarımızda Türkçe ve Yazın Eğitimi. Ankara:

Gül Yayınevi, 1978.

Göktürk, A. Okuma Uğraşı. İstanbul: Çağdaş Yayın, 1980. . Sözün Ötesi. İstanbul: YKY, s.99-103, 2000.

Grant, R. "Strategic Training for Using Text Headings to Improve Students Processing of Content" Journal of Reading . XXXVI, 6 s.482, 1993.

Grice H.P. "Logic and Conversation" P.Cole(editor) Sentax and Semantics Vol.3, Speech Acts, New York: Academic Press, 1995.

Günay, D. Metin Bilgisi. İstanbul: Multılıngual, 2001.

Halliday, M.A.K. and R.Hasan. Cohesion in English. London: Longman, 1976.

Heyd ,G. Grundwissen für den Unterricht in Deutsch als Fremdspache Frankfurt: Moritz Diester Verlay, 1991.

Hinter, E. Reading Skills: A Systematic Approach. Oxford: Alden Press, 1977.

Irwin, J.W. Teaching Reading Comprehension Process (2.nd. Ed) U.S.A. : Allyn and Bacon, 1991.

İpşiroğlu, Z. Okumayı Öğretme. İstanbul: Cem Yayınevi, 1993.

İşeri, K. “Okuma Ediminin Eğitimsel İşlevi”" Dil Dergisi, Ankara, Sayı 70, s.5, 1998.

Jakobsen D., Paul E., Donald K. and Carole D. Methods for Teaching A Skills Approach: "Chapter Eight) Mastery Learning: An Implementation Strategy." Columbus: Charles, E. Merrill Publishing Company, 1985.

Jakobson, R. "Functions of Language". Reading for Applied Linguistics .

Oxford:Ed. J.P.B. Allen Pit Corder, s.52-58, 1980.

Kantemir, E. Türkiye'de Liselerde Türk Dili ve Edebiyatı Öğretimi-Alan Araştırması - İstanbul: MEB Talim ve Terbiye Dairesi Yayını, 1976.

Karasar, N. Araştırmalarda Rapor Hazırlama. Ankara : Bahçelievler P.K.33, 1991.

Kaya, H. “İlkokullarda Türkçe Eğitiminin Verimliliğì” Yayımlanmamış Uzmanlık Tezi, A. Ü. Sos. Bil. Ens., 1985. 
Kaynakçıŏlu, M. "Başarılı ve Daha Az Başarılı Okurların Metin Okuma-Anlama Stratejilerinin Karşılaştırılması " Yayımlanmamış Y.Lis. Tezi, Eskişehir: A.Ü.

Sos.B.Ens. 1999.

Keçik İ. ve Uzun L. Sözlü ve Yazılı Anlatım. Eskişehir: Anadolu Üniversitesi Yay., 2002. Kıran, Z. Dilbilim Akımları. Ankara: Onur Yayınları, II. Baskı, 1996.

Kıran, E.A. ve Kıran Z. Yazınsal Okuma Süreçleri. Ankara: Seçkin Yayınevi, 2000. Kocaman, A.ve dĭg. Söylem Üzerine. Hitit Yayınevi, 1996.

Kuzu, T. "Yabancı Dil Öğretiminde Okuma- Anlama Becerisinin Kazandırılması" Yayımlanmamış Doktora Tezi, Eskişehir: Anadolu Ü. Sosyal Bilimler Ens, 1999.

Lyons, J. Semantics I and II. Essex:Longman, 1977.

Meyer, B.J.F. The organization of prose and its effects on memory. Amsterdam:

North Holland Pub. Co., 1975.

Meyer, B.F. and Freedle, R.. Effects of Discourse Type on Recall, American Educational Research Journal, 21(1):

s.72-103, 1984.

Mungan, M. Meskalin 60 draje. Metis Yayınları, 2000.

Oğuzkan, F. "Okuma Öğretimi" Türk Dili ve Edebiyatı Öğretimi. Eskişehir:Anadolu Ü. Açık Öğretim Fakültesi Yayını, 1991.

Oktar, L., Yağcıoğlu A.S. “ Metnin Retorik Yapısının Okuma Anlama Becerisi Üzerindeki Etkileri “ VII. Dilbilim Kurultayı Bildirileri. Ankara:Dil ve Tarih Coğrafya Fak. Yayını, s.171-179, 1993.

Osam, V,Ü. "Anadilde ve Yabancı Dilde Öğrenme Biçimleri" VII. Dilbilim

Kurultayı Bildirileri. Ankara: A.Ü. Dil ve Tarih-Coğrafya Fak.Yayını s.43, 1993.

Osam, V.Ü. ve Kaçar I. "Yabancı Dilde Okuma-Anlama ile Metinlerin Retorik Yapılarını Tanıma Arasındaki İlişki".

IX. Dilbilim Kurultayı Bildirileri. Bolu: Abant İzzet Baysal Ü. Yayın1, s.15-22, 1995.

Oxford, R.L. "Research on Language Learning Strategies" Annual Review of Applied Linguistics, 13, s.175-187, 1993.

Özcan, M. "İletişimde Şemanın Yeri" Dil Dergisi. Ankara: Say1 74, s.37-47, 1998.

Özçelik, D.A. Ĕgitim Programları ve Öğretim: "Genel Öğretim Yöntemi". Ankara: ÖSYM Eğitim Yayını, 1987.

Özdemir, E. "Anadili Öğretimi" Türk Dili ,Dil Öğretimi Özel Sayısı. Ankara: TDK, s. 5$18,1983$.

. Okuma ve Metin Inceleme. Eskișehir: A.Ü.Açıköğretim Fakültesi, 1991.

. Okuma Sanatı. İstanbul: İnkılap Kitabevi, 1995.

. Eleştirel Okuma. Ankara: Ümit Yayınc1lık, 1995.

Petöfi, J.S. ve diğ. "A Formal Semiotic Text Theory as an IntegtatedTheory of Natural Conguage (Metodological

Remarks)" Current Trends in Text Linguistics, (Haz. V.U.Dressler, de Gruyter, Berlin-New 
York, 1978.

Petöfi, J.S. ve diğ. "Text Connexity, Cohesion”, Coherence: Text Connexity Text Coherence (Haz. E.Sözer),

Buske, Hamburg, 1986.

Polat, T. "Kültürlerarası Bildirişimde Etkin Bir Süreç: Yabancı Dilde Okuma Anlama" Alman Dili ve Edb. Dergisi . İstanbul: İ.Ü. Edb.Fak. s.69-90, 1990.

Richgels, D.J., et al. "Awareness of Four Text Structures: Effects on Recall of Expository Text". Reading Research Quarterly. 12(2): s.177, 1987.

Rumelhart, D.E. "Toward an İnteractive Model of Reading. In effects of Rhetorical Organization on ESL Readers” TESOL Quarterly. 18(3): s.446, 1977.

.Notes on a Schema for Stories. In D.Bobrow and A.Collins (Eds.), Representation Understanding: Studies in Cognitive Sciences. New York: Academic Press, 1980.

Salatac1, R. "Reading Strategies in Turkish and English: A Case Study of Eight Turkish EFL Students" Yayımlanmamış Y.Lis. Tezi, Boğaziçi Ü. Sosyal Bil. Ens., 1997.

Saukkonen, P. "What are the Main Semantic-Pragmatic Features of Stylistic Text Types?" Finland: University of Oulu .

Sarıkaya, C.N. "An Assesment of Percieved Reading Strategy Needs of EFL Learners at BUSEL" Yayımlanmamış Y.Lis.Tezi, Bilkent Ü., 1997.

Sever, S. "Ortaöğretimde Türk Dili ve Edebiyatı Dersi Programlarının Değerlendirilmesi" Yayımlanmamış Uzmanlık Tezi, Ankara Üniversitesi Sosyal Bilimler Enstitüsü, 1985. .Türkçe Öğretimi ve Tam Öğrenme. Ankara: Anı Yayıncılık, 2000.

Smith, C.E. Needs Assesment Guide. Tennessee Department of Education., 1989.

Tekin, H. Okullarımızda Türkçe Eğitimi. Ankara: Mars Matbaası, s. 10-49, 1980.

Türkoğlu, A., A. Doğanay, A. Yıldırım. Ders Çalışma Becerileri. Adana:Baki Kitabevi, s.67-76, 1996.

Varış, F. Eğitim Bilimine Giriş. Ankara: Ankara.Ü. Eğitim Fakültesi, 1981.

Wenden, A. "Learner Strategies For Learner Autonomy: Planning and İmplementing Learning Training For Language Learners" Englewood Cliffs, NJ:Prntice Hall, s.1,2 , 1991

Weinstein, C.E. , R.E.Mayer "Teaching of Learning Strategies" New York: Macmillan Company, 1986.

Wilson, J. Dil Anlam ve Doğruluk. Ankara: Ankara Okulu Yayınları, 2002.

Yavuz, H. Denemeler, "Yavaşlığa Övgü" İstanbul, 1996 .Denemeler, “Tartışma Geleneği” İstanbul, 2000. 